\title{
Comparison of operational performance and analytical model of high concentrator photovoltaic thermal system at 2000 concentration ratio
}

\author{
Emmanuel Shittu ${ }^{1, *}$, Filippo Paredes ${ }^{2}$, Benedetto Schiavo $^{2}$, Luca Venezia $^{2}$, Sergio Milone ${ }^{2}$, Fabio Montagnino ${ }^{2}$, and Maria \\ Kolokotroni ${ }^{1}$ \\ ${ }^{1}$ Brunel University London, Institute of Energy Futures, Kingston Lane, Uxbridge, UB8 3PH, UK \\ ${ }^{2}$ IDEA SRL, Contrada Molara - Zona Industriale Terza Fase - 90018, Termini Imerese (PA), Italy
}

\begin{abstract}
This paper presents the development of a model based on efficiency equations to evaluate the performance of an HCPV/T system and compares its outputs with data of an operational case-study system installed in Palermo, Italy. The model is validated with data of the operational system to show real performance. The model can evaluate (a) the electric efficiency of the InGaP/InGaAs/Ge TJ solar cell and (b) electrical and thermal power/energy production potential of one module. The model predictions are compared with experimental electric and thermal data by obtaining linear regression plots of experimental results vs. analytical results; the $R^{2}$ for experimental electrical and thermal results are 0.91 and 0.87 respectively. Using the model, the evaluated average daily analytical and experimental $\operatorname{lnGaP} / \operatorname{lnGaAs} / \mathrm{Ge} \mathrm{TJ}$ solar cell efficiencies are $33 \%$ and $25 \%$ respectively; with a maximum daily experimental value of $30 \%$. It was found that the annual analytical and potential (based on derived equations from experimental data) electric energy produced by one module are $158 \mathrm{kWh} / \mathrm{m}^{2} /$ year and $144 \mathrm{kWh} / \mathrm{m}^{2} /$ year respectively, while the annual analytical and potential thermal energy are $375 \mathrm{kWh} / \mathrm{m}^{2} /$ year and $390 \mathrm{kWh} / \mathrm{m}^{2} /$ year respectively.
\end{abstract}

\section{Introduction}

Concentrator Photovoltaic (CPV) is an innovative solar technology that is available commercially, and continuously being researched and developed for application in regions of high Direct Normal Irradiance (DNI). This interest is due to the continuous increase in CPV efficiencies, potential increase in power density with the reduction in the land area required to install CPV systems [1]. CPV system makes use of Photovoltaic (PV) cell and optical technologies to produce electric energy, while Concentrator Photovoltaic Thermal (CPV/T) system integrates thermal technology to produce electric and thermal energy. CPV system works by concentrating DNI via optical devices on a very small area of the solar cell. The optical technology usually consists of the reflector and a receiver located at the focal point of the reflector. The DNI concentration is achieved by a sun-tracking system. The PV cell and the thermal energy capture technologies consist of MultiJunction Solar Cell (MJSC) and heat dissipation system. The main advantages of CPV systems are a reduction in the solar cell area, and reduction in land use area, while the main disadvantage is that its use is limited to regions of high DNI, and requires very accurate tracking system [2]-[5].

This paper is a contribution to the application of the $\mathrm{CPV} / \mathrm{T}$ system with Indium-Gallium-Phosphide/Indium-

\footnotetext{
* Corresponding author: emmanuel.shittu@brunel.ac.uk
}

Gallium-Arsenide/Germanium (InGaP/InGaAs/Ge) TJ solar cell, and continuation of previous work on $\mathrm{HCPV} / \mathrm{T}$ system with $\mathrm{InGaP} / \mathrm{InGaAs} / \mathrm{Ge} \mathrm{TJ}$ solar cell, tested at 2000 suns in the lab by [6]-[9]. [7], [8] presented a study on the development of HCPV/T 2000x system using experimental lab data to evaluate the electrical and thermal efficiencies. [6], [9] presented a study on electrical characterisation of $\mathrm{InGaP} / \mathrm{InGaAs} / \mathrm{Ge}$ TJ solar cell and optical characteristics of the reflective concentrator and BK7 glass frustum (refractive concentrator) at 2000 suns. This paper presents the development of a model based on efficiency equations validated with field-based data of the operational HCPV/T 2000x system to evaluate the electric efficiency of $\mathrm{InGaP} / \mathrm{InGaAs} / \mathrm{Ge} \mathrm{TJ}$ solar cell, and electrical and thermal power/energy production potential one $\mathrm{HCPV} / \mathrm{T}$ 2000x module.

\section{Description of the operational high concentrator photovoltaic thermal 2000x system}

Fig. 1 shows the operational cogeneration system that uses solar energy to produce electrical and thermal power, operating at $2000 \mathrm{x}$ concentrations factor. The analysed module 2 is one of the four modules linked together via a reverse return hydraulic layout of the 
active cooling system that uses demineralised water. The active cooling system contains active heatsink integrated with each $\mathrm{InGaP} / \mathrm{InGaAs} / \mathrm{Ge}$ TJ solar cell with the design to simultaneously keep the $\mathrm{InGaP} / \mathrm{InGaAs} / \mathrm{Ge} \mathrm{TJ}$ solar cell at the operating temperature of $20{ }^{\circ} \mathrm{C}$ to $90{ }^{\circ} \mathrm{C}$ (with a maximum temperature of $110{ }^{\circ} \mathrm{C}$ ) and extract thermal energy by means of the flowing demineralised water. The active heat sink is designed with one inlet and one outlet entry point, and a heat exchanger between the $\mathrm{InGaP} / \mathrm{InGaAs} / \mathrm{Ge} \mathrm{TJ}$ solar cell and the flowing demineralised water. The analysed HCPV/T 2000x module is divided into two semi-modules (North-side (N-side) and South-side (S-side)). The main components of the analysed module essential to its operation are:

- $20 \mathrm{InGaP} / \mathrm{InGaAs} / \mathrm{Ge} \mathrm{TJ}$ solar cells each integrated with an active heat sink,

- 20 reflective ultraclean off-axis parabolic mirror,

- 20 tapered-rectangular BK7 frustum optical receiver at the focal point of the reflective mirror,

- 2-axis tracking system based on alt-azimuth angles, Steel A286 iron base superalloy frame structural support, - Complementary Metal Oxide Semiconductor (CMOS) webcam.

The surface area of each $\mathrm{InGaP} / \mathrm{InGaAs} / \mathrm{Ge} \mathrm{TJ}$ solar cell $\left(A_{c}\right)$ is $107.90 \mathrm{~mm}^{2}(10.3875 \mathrm{~mm} \times 10.3875 \mathrm{~mm})$, the surface area of the reflective mirror $\left(A_{r}\right)$ is $2025 \mathrm{~cm}^{2}$ $(45 \mathrm{~cm} \mathrm{x} 45 \mathrm{~cm})$, the surface area of the BK7 frustum at the focus point of the reflective mirror is $256 \mathrm{~mm}^{2}$ (16 $\mathrm{mm} \times 16 \mathrm{~mm}$ ), while the tapered surface area of the BK7 frustum at the point of contact with the InGaP/InGaAs/Ge TJ solar cell is $107.90 \mathrm{~mm}^{2}$. The 2000x operating condition is achieved by the 2-axis tracking system aligned in the North-South (N-S) configuration, in order to effectively track the sun via simultaneous rotational motion of the N-S longitudinal axle, and tilting motion of the East-West (E-W) transverse axle. The rotational motion of the N-S longitudinal axle and tilting motion of the E-W transverse axle are provided by the installed Bernio MR $61530 \mathrm{Q} 1 / 1024$ coaxial gear rotational motor and actuator Linak LA25 linear motor respectively, with each motor connected to an AN8 magnetic encoder position sensor. The Solar Position Algorithm (SPA) of National Renewable Energy Laboratory's (NREL) is an astronomical tracking algorithm used to track the suns position. The tracking accuracy for a visible clear sky sunny day is increased with the CMOS webcam installed in the $\mathrm{N}$-side of the module configuration.

The HCPV/T 2000x module electric circuit is connected to a $1000 \mathrm{~W}$ smart grid tie variable load micro-inverter. A control panel manages the 2-axis tracking system and acquires operative parameters (such as current, voltage, flow rates, demineralised water temperature, solar position angles etc.). The electric layout of one module consists of a parallel circuit arrangement of the two semi-modules (N-side and Sside); each semi-module consists of 10 series of InGaP/InGaAs/Ge TJ solar cells. Similarly, to the electrical system, the hydraulic/thermal system is connected to the control panel. Two YF-S401 volumetric flow-meters; that measures flow rate between $0.3 \mathrm{~L} / \mathrm{min}$ $\left(5 \times 10^{-6} \mathrm{~kg} / \mathrm{s}\right)$ to $6 \mathrm{~L} / \mathrm{min}\left(1 \times 10^{-4} \mathrm{~kg} / \mathrm{s}\right)$ at water pressure
$0.8 \mathrm{MPa}$ gauge with an accuracy of $\pm 5 \%$, are installed in the East-side (E-side) and West-side (W-side) of each semi-module. Each semi-module has one inlet and one outlet PT100 platinum thermometer sensor with an accuracy of $\pm 0.05 \%$. The values of the electrical and thermal operating parameters are measured and recorded in a MySQL database.

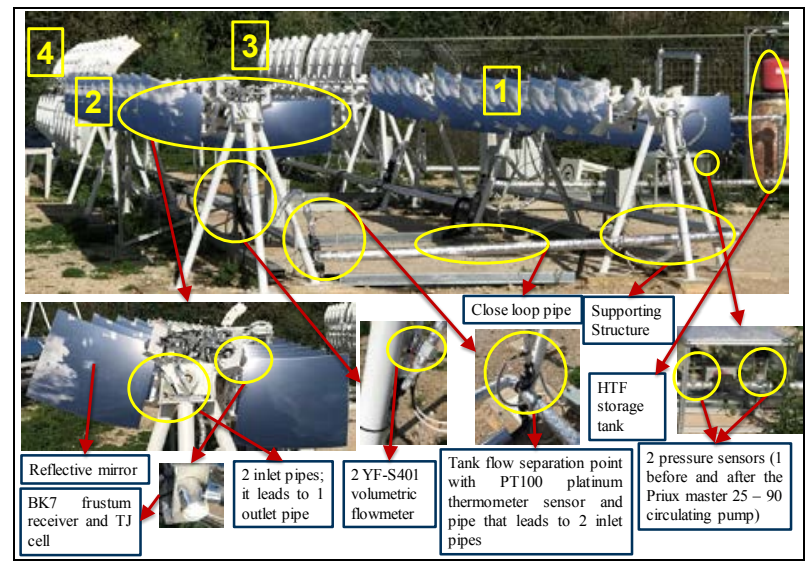

Fig. 1. HCPV/T 2000x module system. The numbers indicate the position of the four modules; this work focusses on module 2.

The thermal system consists of 20 active heat sinks (a sink for each solar cell) cooling system that uses demineralised water as a Heat Transfer Fluid (HTF). The cooling system is designed to keep the 20 $\mathrm{InGaP} / \mathrm{InGaAs} / \mathrm{Ge}$ TJ solar cells operating at the designed temperature range of $20{ }^{\circ} \mathrm{C}$ to $90{ }^{\circ} \mathrm{C}$ (with a maximum temperature of $110^{\circ} \mathrm{C}$ ). Each active heatsink is equipped with a $100 \mathrm{~mm}^{2}$ Aluminium (Al) heat exchanger plate to extract the thermal energy. A Priux master $25-90$ circulating pump and a $0.2 \mathrm{~m}^{3}$ demineralised water storage tank are integrated in the closed-loop hydraulic system.

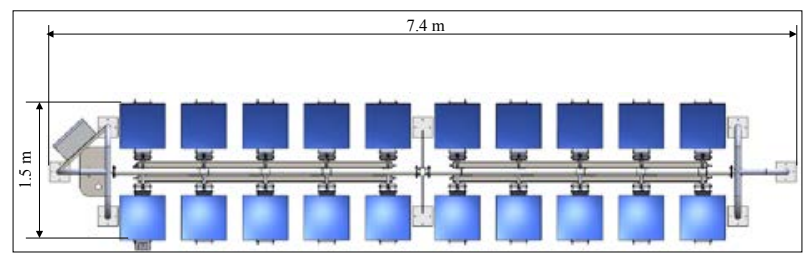

Fig. 2. HCPV/T Module 2; footprint area is equal to $11 \mathrm{~m}^{2}$

\section{Model development for the high concentrator photovoltaic thermal 2000x system}

The HCPV/T 2000x module was analysed in terms of:

- InGaP/InGaAs/Ge TJ solar cell efficiency,

- Electric and thermal power/energy outputs (for yearly, monthly, daily and hourly time levels). 


\subsection{Triple junction cell efficiency}

The operating cell temperature is an important parameter required to calculate cell efficiency. The actual operating temperature of the $\mathrm{InGaP} / \mathrm{InGaAs} / \mathrm{Ge} \mathrm{TJ}$ solar cell was not considered in the calculation of the cell efficiency because the assembled active heatsink does not have temperature sensor amongst its components due to its complexity. Instead, an effective cell efficiency equation as a function DNI $\left(G_{i}\right)$ was applied.

The analytical cell efficiency was derived as a function of $G_{i}$, referring to cell efficiency vs. CR (up to 1500) characteristic obtained from two experimental tests performed using the same type of $\mathrm{InGaP} / \mathrm{InGaAs} / \mathrm{Ge} \mathrm{TJ}$ solar cell installed in $\mathrm{HCPV} / \mathrm{T}$ 2000x module. The experimental tests were performed on $30.25 \mathrm{~mm} 2(5.5 \mathrm{~mm} \times 5.5 \mathrm{~mm})$ and $100 \mathrm{~mm}^{2}(10 \mathrm{~mm}$ $\mathrm{x} 10 \mathrm{~mm}$ ) at Test Conditions (TC) of $25^{\circ} \mathrm{C}, 1000 \mathrm{~W} / \mathrm{m}^{2}$ and $500 \mathrm{~W} / \mathrm{m}^{2}$ [10], [11]. The cell efficiency vs. CR characteristic obtained from both tests was extrapolated for CR up to 2000 to match the CR of the analysed HCPV/T 2000x system. Thus, the analytical cell efficiency equation was derived as a function of $G_{i}$. Therefore, the derived analytical $\mathrm{InGaP} / \mathrm{InGaAs} / \mathrm{Ge} \mathrm{TJ}$ solar cell efficiency is:

$$
\eta_{c, t h r}=a \cdot G_{i}+b
$$

where $a=0.00003 \mathrm{~m}^{2} / \mathrm{W}$ and $b=0.3102$.

Due to current mismatch loss caused by different operating conditions (such as shading) experienced by the InGaP/InGaAs/Ge TJ solar cells connected in series, the HCPV/T 2000x electric circuit efficiency is assumed to be $90 \%$ (i.e. $\eta_{s}=0.9$ ) of the solar cell efficiency [2], [12]-[14]. Therefore, analytical electric HCPV/T 2000x circuit efficiency is:

$$
\eta_{c i r c, t h r}=\eta_{s} \cdot \eta_{c, t h r}
$$

The experimental HCPV/T 2000x electric circuit efficiency is:

$$
\eta_{\text {circ,exp }}=P_{\text {el, }, \text { exp }} /\left(\eta_{\text {opt }} \cdot f_{t} \cdot G_{i} \cdot A_{r} \cdot N\right)
$$

where $P_{e l, p, e x p}, \eta_{o p t}, A_{r}, f_{t}$, and $N$ are experimental produced electric power, combined optical efficiency of the reflective mirror and BK7 frustum receiver, surface area of the reflective mirror, non-ideal tracking factor of the 2-axis tracking system, and the number of cells respectively. $\eta_{\text {opt }}$ and $f_{t}$ are equal to 0.85 and 0.9 respectively [2], [12], [15].

The experimental $\mathrm{InGaP} / \mathrm{InGaAs} / \mathrm{Ge}$ TJ solar cell efficiency is:

$$
\eta_{c, \exp }=\eta_{\text {circ,exp }} / \eta_{s}
$$

\subsection{Analytical analysis of electric and thermal power}

The analytical electric power produced by one 107.90 $\mathrm{mm}^{2} \mathrm{InGaP} / \mathrm{InGaAs} / \mathrm{Ge}$ TJ solar cell at $2000 \mathrm{CR}$ is [14], [15]:

$$
P_{c, p, t h r}=\eta_{c, t h r} \cdot \eta_{o p t} \cdot C F \cdot f_{t} \cdot A_{c} \cdot G_{i}
$$

The analytical electric power produced by the module with $N$ number of $\mathrm{InGaP} / \mathrm{InGaAs} / \mathrm{Ge}$ TJ solar cells is [14], [15]:

$$
P_{e l, p, t h r}=P_{c, p, t h r} \cdot N \cdot \eta_{s}
$$

The analytical thermal power produced by the module is [2], [12]-[14]:

$$
Q_{t h, p, t h r}=\left(1-\eta_{\text {circ, thr }}\right) \cdot \eta_{o p t} \cdot C F \cdot f_{t} \cdot A_{c} \cdot G_{i} \cdot N
$$

\subsection{Experimental monitoring analysis of electric and thermal power}

The experimental electric power produced by the module is:

$$
P_{e l, p, e x p}=I \cdot V
$$

where $P_{\text {el,pexp }}$ is the product of experimental measured HCPV/T 2000x electric circuit variable voltage $(V)$ and current $(I)$; the HCPV/T 2000x electric circuit is connected to $1000 \mathrm{~W}$ smart grid tie variable load micro-inverter in order to achieve instantaneous maximum power.

The potential electric power produced by one HCPV/T 2000x module at any given time in a typical year can be calculated by using the derived potential produced electric power $\left(P_{e l, p, d e r}\right)$ as a function of $G_{i}$ described in equation (9); this was obtained from the plot (Fig. 3) of $P_{\text {el,p,exp }}$ against $G_{i, \text { exp }}$ (with Coefficient of Determinant $\left.\left(R^{2}\right)=0.91\right)$ for experimental results between $1^{\text {st }}$ March 2018 and the $22^{\text {rd }}$ May 2018. The derived potential produced electric power equation was then used to calculate the monthly/annual potential electric energy produced by one module, using Meteonorm DNI $\left(G_{i, m e t}\right)$ data obtained from Meteonorm weather file for Palermo, Sicily [16]. The derived potential produced electric power is:

$$
P_{e l, p, d e r}=c \cdot G_{i}+d, \text { for } G_{i} \geq 60 \mathrm{~W} / \mathrm{m}^{2}
$$

where $c=0.5 \mathrm{~m}^{2}$ and $d=71.1 \mathrm{~W}$.

The experimental thermal power produced by the module is:

$$
Q_{\text {th,pexp }}=\rho_{w} \cdot V_{o l} \cdot c_{w} \cdot\left(T_{\text {out }}-T_{\text {in }}\right)
$$

where the demineralised water volumetric flow rate $\left(V_{o l}\right)$, outlet temperature $\left(T_{o u t}\right)$ and inlet temperature $\left(T_{i n}\right)$ for the single module were measured by the installed YF-S401 volumetric flowmeter and PT100 platinum thermometers temperature sensors respectively. The water density $\left(\rho_{w}\right)$ was calculated as a function of water temperature according to the following equation with $R^{2}$ $=0.99[17]$ :

$$
\rho_{w}=-0.0035 \cdot\left\{\left[\left(T_{\text {out }}+T_{\text {in }}\right) / 2\right]^{2}\right\}-0.0842 \cdot\left[\left(T_{\text {out }}+T_{\text {in }}\right) / 2\right]+\rho
$$


where $\rho=1000.8 \mathrm{~kg} / \mathrm{m}^{3}$ at water temperature equal to $0{ }^{\circ} \mathrm{C}$.

The plot (Fig. 4) of $\left(T_{\text {out }}-T_{\text {in }}\right)$ and $\left[\left(T_{\text {out }}+T_{\text {in }}\right) / 2\right]$ against $G_{i, e x p}$ (for experimental results between $1^{\text {st }}$ March 2018 and the $22^{\text {rd }}$ May 2018) shows a linear relation; $\left(T_{\text {out }}-T_{\text {in }}\right)$ and $\left[\left(T_{\text {out }}+T_{\text {in }}\right) / 2\right]$ increases as $G_{i, e x p}$ increases. A linear equation of $\left(T_{\text {out }}-T_{\text {in }}\right)$ as a function of $G_{i}$ (with $R^{2}$ $=0.93)$ was derived from the plot. Also, a linear equation of $\left[\left(T_{\text {out }}+T_{\text {in }}\right) / 2\right]$ as a function of $G_{i}$ (with $\mathrm{R}^{2}=$ $0.60)$ was derived from the plot. Equation of $\left(T_{\text {out }}-T_{i n}\right)$ and $\left[\left(T_{\text {out }}+T_{\text {in }}\right) / 2\right]$ are:

$$
\begin{gathered}
\left(T_{\text {out }}-T_{\text {in }}\right)=e \cdot G_{i}+f \\
{\left[\left(T_{\text {out }}+T_{\text {in }}\right) / 2\right]=g \cdot G_{i}+h}
\end{gathered}
$$

where $e=0.0056 \mathrm{~K} \mathrm{~m}^{2} / \mathrm{W}, f=273.69 \mathrm{~K}, g=0.0134$ $\mathrm{K} \mathrm{m}^{2} / \mathrm{W}, h=297.33 \mathrm{~K}$.

Therefore, the potential thermal power produced by one HCPV/T 2000x module at any given time in a typical year can be calculated by using equation (10), and the derived equations (11) to (13). These equations were then used to calculate the monthly/annual potential thermal energy produced by one module, using Meteonorm DNI $\left(G_{i, \mathrm{met}}\right)$ data obtained from Meteonorm weather file for Palermo, Sicily [16].

\subsection{Experimental data}

The experimental monitoring analysis of the HCPV/T 2000x module was conducted for 78 days $\left(1^{\text {st }}\right.$ March 2018 and $25^{\text {th }}$ June 2018). The system did not operate or produce electric and thermal power for 39 days within this period either due to needed technical modifications or bad weather conditions.

Experimental measured DNI $\left(G_{i, e x p}\right)$ data (measured and recorded in a MySQL database) used to analyse the module production from $1^{\text {st }}$ March 2018 to $25^{\text {th }}$ June 2018 was obtained from 2-axis alt-azimuth STR-22G sun tracker installed on-site, while the Meteonorm DNI $\left(G_{i, m e t}\right)$ used to calculate the monthly/annual potential electric and thermal energy produced by one module was obtained from Meteonorm weather file for Palermo, Sicily [16].

The presented experimental analysed results considered 25 days (16 days (between $1^{\text {st }}$ March 2018 and $22^{\text {nd }}$ May 2018) for when the circulating active cooling demineralised water was not bypassed from the $0.2 \mathrm{~m}^{3}$ demineralised water storage tank, and 9 days (between $23^{\text {rd }}$ May 2018 and $25^{\text {th }}$ June 2018) for when it was bypassed) with 5 to 10 hours of electrical and thermal production between 6 am to $3 \mathrm{pm}$. However, for derived equations (9), (12) and (13), experimentally measured data considered 42 days for when the circulating active cooling demineralised water was not bypassed from the $0.2 \mathrm{~m}^{3}$ demineralised water storage tank, between 6 am and $7 \mathrm{pm}$. The current, voltage, temperature, volumetric flow rate, and DNI were recorded on average six times per minute. The obtained experimental measured data were used to evaluate the $\mathrm{InGaP} / \mathrm{InGaAs} / \mathrm{Ge}$ TJ solar cell efficiency, and electric and thermal power/energy. Finally, using the derived electric power (Fig. 3), the demineralised water temperature expressions (Fig. 4) from the analysed experimentally measured data and the DNI input data from Meteonorm [16], the monthly and hence annual potential electric and thermal energy were evaluated. Fig. 3 and Fig. 4 shows that the electric and thermal power increases with increasing DNI.

Since, the actual operating temperature of the InGaP/InGaAs/Ge TJ solar cell was not measured, the measured temperature of the cooling demineralised water was used as a reference parameter (because the cell temperature will always be greater) to characterise the behaviour of the InGaP/InGaAs/Ge TJ solar cell with change in temperature. As shown in Fig. 5 and Fig. 6 (the experimental results plots for when the circulation active cooling demineralised water was bypassed from the $0.2 \mathrm{~m}^{3}$ demineralised water storage tank), the cell efficiency increases with increase in the demineralised water temperature (hence the $\mathrm{InGaP} / \mathrm{InGaAs} / \mathrm{Ge} \mathrm{TJ}$ solar cell temperature), before showing a gradual decrease from the operating optimum demineralised water temperature of approximately $30{ }^{\circ} \mathrm{C}$, to the maximum demineralised water temperature of approximately 53 ${ }^{\circ} \mathrm{C}$.

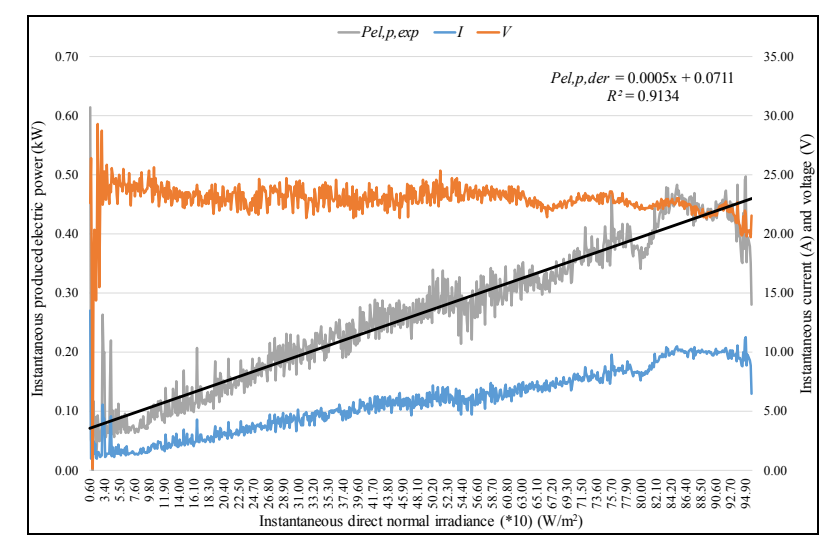

Fig. 3. HCPV/T 2000x system; instantaneous produced electric power, current, and voltage vs. instantaneous DNI (the DNI values are multiple of 10); 42 days between the $1^{\text {st }}$ March 2018 and the $22^{\text {nd }}$ May 2018).

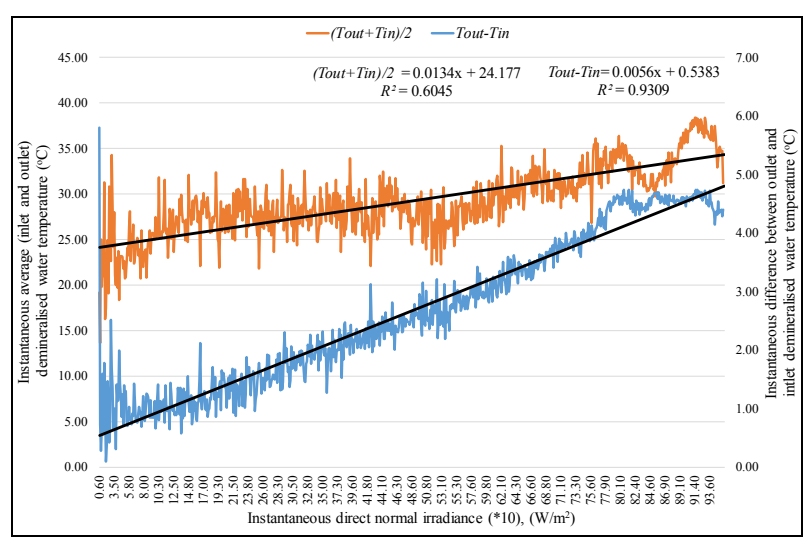

Fig. 4. HCPV 2000x system; instantaneous demineralised water temperature vs. instantaneous DNI; (the DNI values are multiple of 10); 42 days between the $1^{\text {st }}$ March 2018 and the $22^{\text {nd }}$ May 2018). 


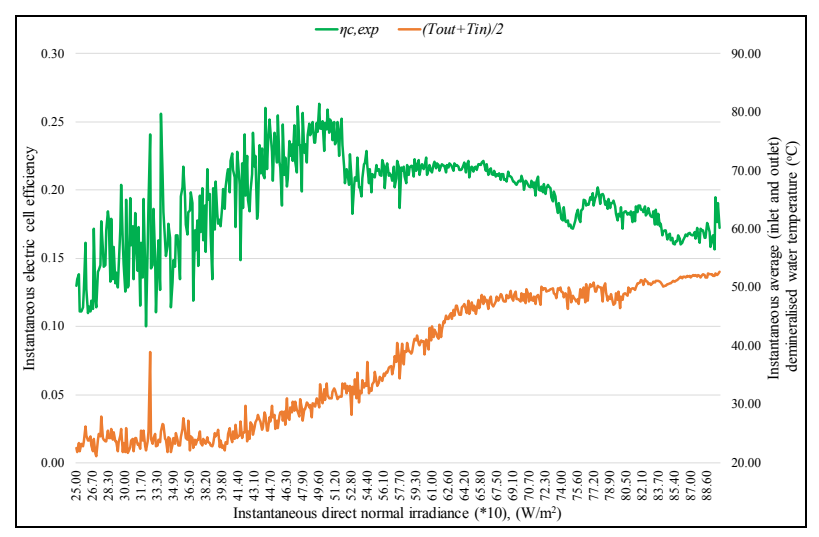

Fig. 5. HCPV/T 2000x system; instantaneous electric InGaP/InGaAs/Ge TJ solar cell efficiency and demineralised water temperature vs. instantaneous DNI (the DNI values are multiple of 10$) ; 9$ days $\left(24^{\text {th }}, 25^{\text {th }}\right.$, and $30^{\text {th }}$ May, and $2^{\text {nd }}, 3^{\text {rd }}$, $10^{\text {th }}, 11^{\text {th }}, 12$ th and $22^{\text {nd }}$ June 2018) between 6 am and $3 \mathrm{pm}$.

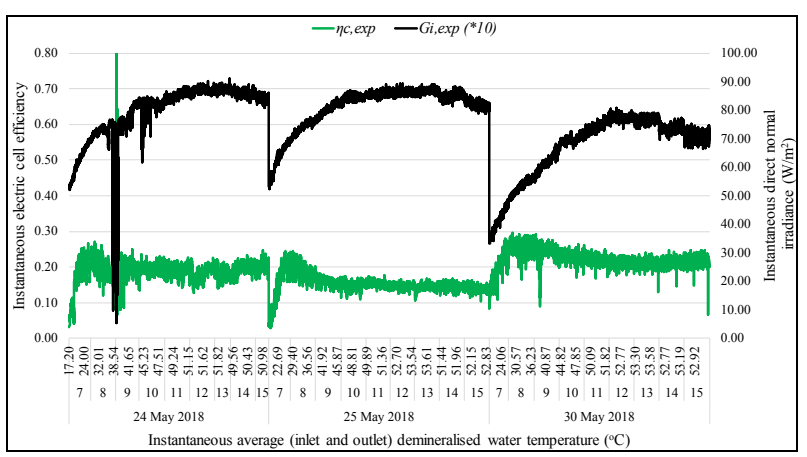

Fig. 6. $\mathrm{HCPV} / \mathrm{T} 2000 \mathrm{x}$ system; instantaneous electric InGaP/InGaAs/Ge TJ solar cell efficiency and DNI (the DNI values are multiple of 10) vs. instantaneous demineralised water temperature; 3 days $\left(24^{\text {th }}, 25^{\text {th }}\right.$, and $30^{\text {th }}$, May) between 6 am and $3 \mathrm{pm}$.

\section{Model development for a fixed angle monocrystalline silicon photovoltaic system}

The objective of developing this model is to carry out a performance comparison between a fixed angle PV and HCPV/T 2000x system. This comparison will be based on PV cell efficiency and electric energy production capability. The PV system model was developed based on the commercially available state of the art monocrystalline silicon PV technology, for Palermo case-study location. Specifications for the analysed 1.66 $\mathrm{m}^{2}(1.63 \mathrm{~m} \times 1.02 \mathrm{~m})$ state of the art monocrystalline PV panel was taken from [18]. Footprint area of $11 \mathrm{~m}^{2}(7.4$ $\mathrm{m} \times 1.5 \mathrm{~m}$ ) as the HCPV/T 2000x system was used; this equates to approximately $5 \mathrm{PV}$ panel array. The tilt angle of the array was assumed to be $30^{\circ}[19]$.

The analytical monocrystalline silicon PV array produced electric energy is [20]:

$$
E_{e l, p, t h r}=\eta_{c, t h r} \cdot G H I_{i, m e t} \cdot f_{a} \cdot A_{p v} \cdot N_{p v} \cdot \eta_{s}
$$

where $\eta_{c, t h r}, G H I_{i, m e t}, f_{a}, A_{p v}$, and $N_{p v}$ are analytical PV cell efficiency, Meteonorm Global Horizontal Irradiance (obtained from Meteonorm weather file for Palermo, Sicily [16]), fraction of PV panel surface area with active solar cells, Surface area of a PV panel, and number of PV panel respectively.

The analytical monocrystalline silicon PV cell efficiency is [21]:

$$
\eta_{c, s i t h r}=P_{e l, p, \exp } /\left[1-\sigma_{t}\left(T_{c}-T_{r e f}\right)\right]
$$

where $\eta_{r e f}, \sigma_{t}, T_{c}$, and $T_{r e f}$, are reference cell efficiency at Standard Test Conditions (STC), PV temperature coefficient, operating cell temperature, and reference cell temperature respectively. The STC are $T_{r e f}=25{ }^{\circ} \mathrm{C}$, and solar irradiance of $1000 \mathrm{~W} / \mathrm{m}^{2}$ [18], [21]. The $\eta_{\text {ref }}$ and $\sigma_{t}$ are constant experimentally derived values equal to 16.9 $\%$ and $0.44 \% /{ }^{\circ} \mathrm{C}$ respectively [18].

Therefore, analytical monocrystalline silicon PV electric circuit efficiency is:

$$
\eta_{c i r c, s i, t h r}=\eta_{s} \cdot \eta_{c, s i, t h r}
$$

The analytical operating monocrystalline silicon cell temperature is [21]:

$$
T_{c, s i, t h r}=T_{i, a, m e t}+\left[\left(T_{N O C T}-20^{\circ} \mathrm{C}\right) / 800 \mathrm{~W} / \mathrm{m}^{2}\right] \cdot G H I_{i, m e t}
$$

where $T_{i, a, m e t}$ and $T_{N O C T}$, are Meteonorm air temperature (obtained from Meteonorm weather file for Palermo, Sicily [16]) and Nominal Operating Cell Temperature (NOCT) respectively. NOCT is an experimentally derived constant value equal to $46.5{ }^{\circ} \mathrm{C}$ [18].

\section{Comparison of modelled high concentrator photovoltaic thermal 2000x system}

The inputs used for the analytical calculations of the electric cell and circuit efficiencies, and electric and thermal power productions are DNI values and HCPV/T 2000x system component characteristics. The inputs used for the experimental calculations of the electric cell and circuit efficiencies, and electric and thermal power productions are DNI, HCPV/T 2000x component characteristics, measured HCPV/T 2000x electric circuit voltage and current, measured volumetric flow rates and demineralised water temperature.

\subsection{Cell and circuit efficiencies}

The analytical and experimental electric InGaP/InGaAs/Ge TJ solar cell efficiencies were calculated using equations (1) and (4) respectively. The analytical and experimental HCPV/T 2000x electric circuit efficiencies were calculated using equations (2) 
and (3) respectively. As shown in Fig. 7, the average daily analytical electric InGaP/InGaAs/Ge TJ solar cell efficiency follows the pattern of the average daily DNI, however, this is not the case for the average daily experimental electric InGaP/InGaAs/Ge TJ solar cell efficiency. This is because the average daily experimental electric $\mathrm{InGaP} / \mathrm{InGaAs} / \mathrm{Ge} \mathrm{TJ}$ solar cell efficiency is influenced by several factors; mainly the $\mathrm{DNI}, \mathrm{InGaP} / \mathrm{InGaAs} / \mathrm{Ge} \mathrm{TJ}$ solar cell temperature, and demineralised water temperature. The increase in DNI values increases the demineralised water temperature (hence $\mathrm{InGaP} / \mathrm{InGaAs} / \mathrm{Ge} \mathrm{TJ}$ solar cell temperature), leading to a minor reduction in electric InGaP/InGaAs/Ge TJ solar cell efficiency; from the operating optimum demineralised water temperature of approximately $30{ }^{\circ} \mathrm{C}$, to the maximum demineralised water temperature of approximately $53{ }^{\circ} \mathrm{C}$. This is described in Fig. 5. HCPV/T 2000x system; instantaneous electric $\mathrm{InGaP} / \mathrm{InGaAs} / \mathrm{Ge}$ TJ solar cell efficiency and demineralised water temperature vs. instantaneous DNI (the DNI values are multiple of 10); 9 days (24th, 25th, and 30th May, and 2nd, 3rd, 10th, 11th, 12th and 22nd June 2018) between 6 am and 3 pm. and Fig. 6. These figures characterise the behaviour of the InGaP/InGaAs/Ge TJ solar cell with a change in demineralised water temperature (hence InGaP/InGaAs/Ge TJ solar cell temperature). This phenomenon is further buttressed by the behaviour shown in Fig. 7. HCPV/T 2000x system; average daily electric $\mathrm{InGaP} / \mathrm{InGaAs} / \mathrm{Ge}$ TJ solar cell and HCPV/T 2000x circuit efficiencies, average daily DNI (the DNI values are multiple of 10) and average daily demineralised water temperature; 25 days between 9 am and 3 pm.; days with lower average daily DNI have higher average daily experimental $\mathrm{InGaP} / \mathrm{InGaAs} / \mathrm{Ge}$ TJ solar cell efficiency and vice versa.

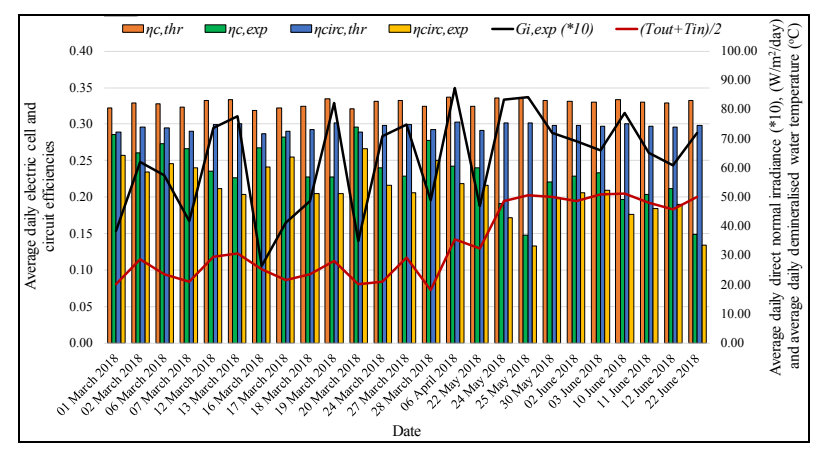

Fig. 7. HCPV/T 2000x system; average daily electric $\mathrm{InGaP} / \mathrm{InGaAs} / \mathrm{Ge}$ TJ solar cell and HCPV/T 2000x circuit efficiencies, average daily DNI (the DNI values are multiple of 10) and average daily demineralised water temperature; 25 days between 9 am and $3 \mathrm{pm}$.

\subsection{Electric and thermal power}

The produced electric and thermal power was calculated using the electric $\mathrm{InGaP} / \mathrm{InGaAs} / \mathrm{Ge} \mathrm{TJ}$ solar cell and HCPV/T 2000x electric circuit efficiencies as inputs in addition to the DNI. The produced average daily analytical electric and thermal power were evaluated using equations (5) and (6) and (7) respectively. The produced average daily experimental electric and thermal power were evaluated using equations (8) and (10) respectively. As shown in Fig. 8, the average daily analytical and experimental produced electric and thermal power follow the pattern of the average daily DNI, which is the main parameter affecting these quantities.

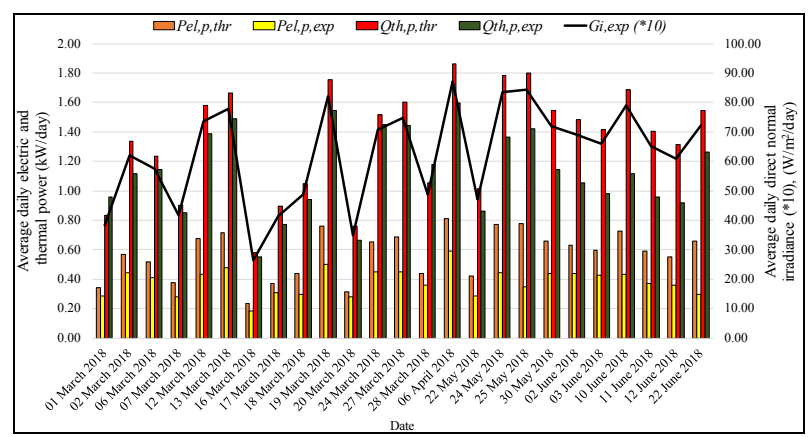

Fig. 8. HCPV/T 2000x system; average daily electric and thermal power, and average daily DNI (the DNI values are multiple of 10) and average daily demineralised water temperature; 25 days between 9 am and $3 \mathrm{pm}$.

\subsection{Monthly and annual production}

The monthly and annual production was evaluated using DNI input data from Meteonorm [16]. The potential produced electric and thermal energy by the HCPV/T 2000x module were evaluated using equations (9) and (10) to (13) respectively. As shown in Fig. 9, the monthly sum of analytical and experimental produced electric and thermal power follows the pattern of the average monthly DNI; with July and February experiencing, respectively, the highest and lowest electric and thermal power production.

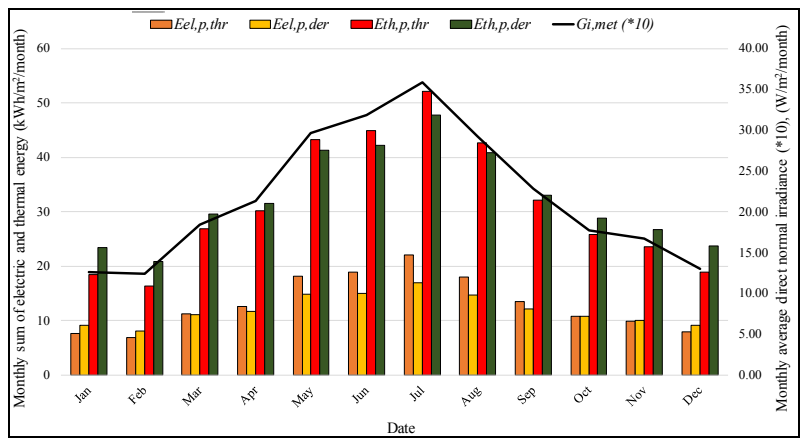

Fig. 9. HCPV/T 2000x system; the monthly sum of electric and thermal energy, and monthly average DNI; for a typical year.

\section{Discussion}

The experimental monitoring and analytical analysis of the HCPV/T 2000x system were performed in order to evaluate the InGaP/InGaAs/Ge TJ solar cell efficiency, and electrical and thermal power/energy production capability. 
According to the results presented in Fig. 7, the calculated average daily analytical and experimental $\mathrm{InGaP} / \mathrm{InGaAs} / \mathrm{Ge} \mathrm{TJ}$ solar cell efficiencies are $33 \%$ and $25 \%$ respectively; a maximum daily experimental InGaP/InGaAs/Ge TJ solar cell efficiency of $30 \%$ was achieved on the 20th of March.

The results presented in Fig. 9 show that, the annual analytical produced electric and thermal energy by the HCPV/T 2000x module are $158 \mathrm{kWh} / \mathrm{m}^{2} /$ year and 375 $\mathrm{kWh} / \mathrm{m}^{2} /$ year respectively, while the annual potential (based on derived equations from experimental analysed results) produced electric energy and thermal energy are $144 \mathrm{kWh} / \mathrm{m}^{2} /$ year and $390 \mathrm{kWh} / \mathrm{m}^{2} /$ year respectively.

Finally, the analysed HCPV/T 2000x system characterised with $\mathrm{InGaP} / \mathrm{InGaAs} / \mathrm{Ge}$ TJ cell has higher electrical efficiency and electric power/energy production capability than the analysed commercially available fixed angle monocrystalline silicon PV system. As shown in Fig. 10 and Fig. 11, the analytically calculated average/maximum daily monocrystalline silicon cell efficiency and annual produced electric energy by the module are $17 \% / 18 \%$ and 117 $\mathrm{kWh} / \mathrm{m}^{2} /$ year, respectively. The analytically calculated monocrystalline silicon cell efficiency shows good correlation with the monocrystalline silicon cell efficiency data published in [22]; the commercially available monocrystalline silicon PV technology has electrical PV cell efficiency between $15 \%$ and $19 \%$. Similarly, the HCPV/T 2000x system has higher electrical efficiency than the PVT technology as published in [22]; the commercially available PV/T technology has electrical PV cell efficiency between 13 and $16 \%$. The amortised cost of the HCPV/T 2000x system over its lifetime isn't included in this paper because the system has not yet been commercialised.

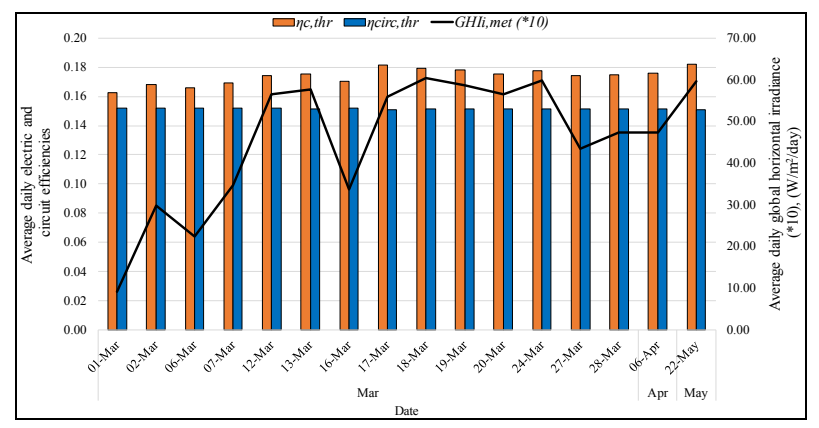

Fig. 10. Monocrystalline silicon PV system; average daily electric and circuit efficiencies, average daily DNI (the DNI values are multiple of 10); 16 days between 9 am and $3 \mathrm{pm}$.

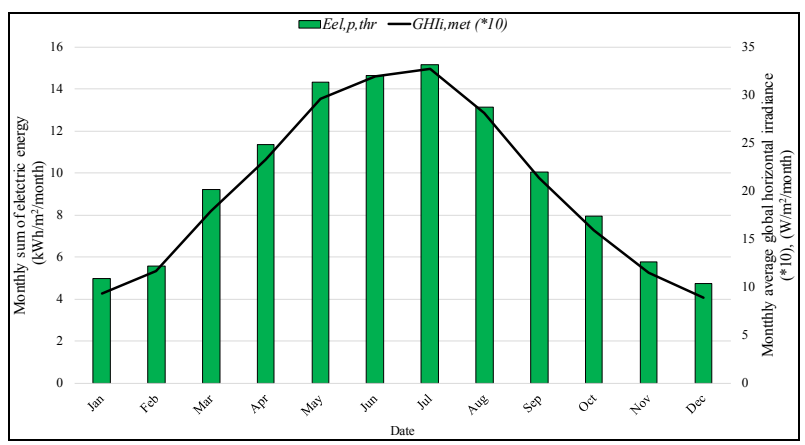

Fig. 11. Monocrystalline silicon PV system; the monthly sum of produced analytical electric energy and monthly average DNI (the DNI values are multiple of 10); for a typical year.

The accuracy of experimental electric and thermal measurements was validated by obtaining linear regression plot (Fig. 12) of experimental results vs. analytical results. The $R^{2}$ for experimental electrical and thermal results are 0.91 and 0.87 respectively.

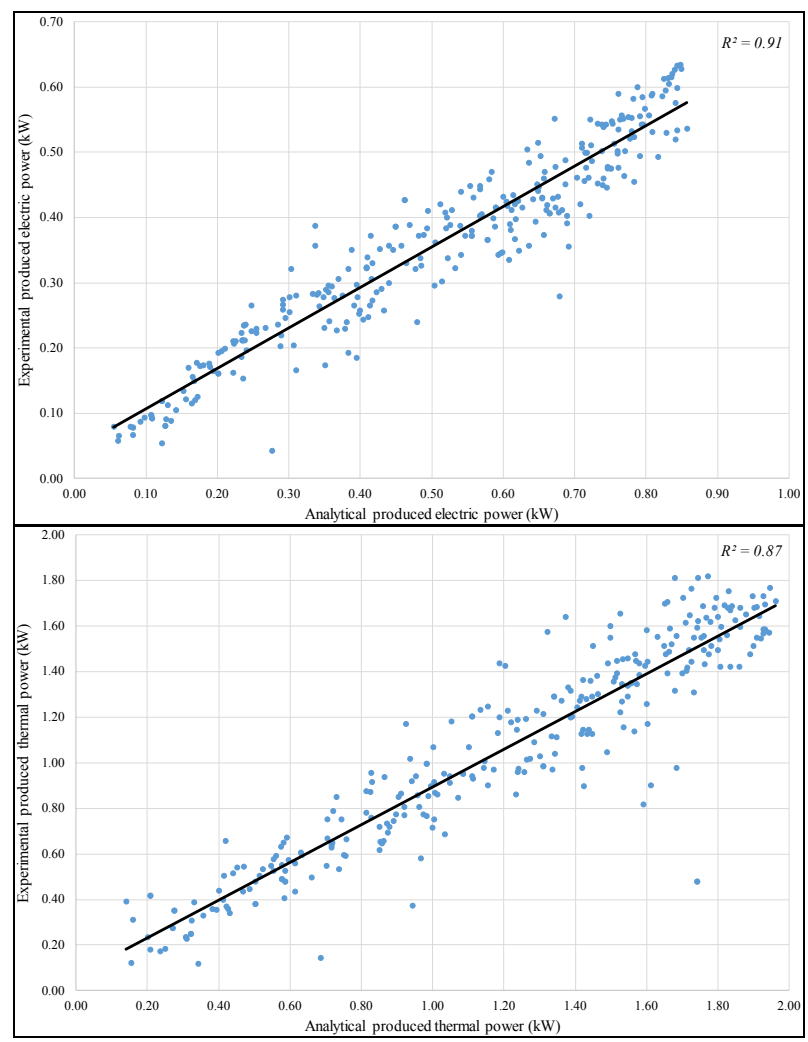

Fig. 12. HCPV/T 2000x system; experimental vs. theoretical values of produced electrical and thermal power; 16 days (between $1^{\text {st }}$ March 2018 and 22 $2^{\text {nd }}$ May 2018) between 9 am and $3 \mathrm{pm}$.

\section{Conclusion}

This study evaluated the operational performance of the HCPV/T 2000x system and developed an analytical model. The analytical model shows good agreement with the operational data. The developed model can be used to calculate the required capacities for a variety of building applications and climatic conditions.

The HCPV/T 2000x system is suitable to meet all/most of the electrical demand for domestic residential 
application and all/most of the hot water demand because the system has the capacity to heat the demineralised water temperature to above $50{ }^{\circ} \mathrm{C}$. This system is also suitable for commercial buildings/facilities that require onsite electrical and thermal power to supplement the electrical and thermal power supply from the grid. The HCPV/T 2000x system is designed with the capacity to produce up to $1 \mathrm{~kW}$ of electric power and $2.0 \mathrm{~kW}$ of thermal power.

This work is part of the SMART GEMS project funded by H2020-MSCA-RISE-2014 (GA No 645677) and FAE project, PO FESR Sicilia 2007/2013 4.1.1.1.

\section{References}

1. S. P. Philipps, A. W. Bett, K. Horowitz, and S. Kurtz, Current Status of Concentrator Photovoltaic (CPV) Technology, Natl. Renew. Energy Lab., pp. 1-25, (2015).

2. C. Renno and F. Petito, Design and modeling of a concentrating photovoltaic thermal (CPV/T) system for a domestic application, Energy Build., vol. 62, pp. 392-402, (2013).

3. O. Z. Sharaf and M. F. Orhan, Concentrated photovoltaic thermal (CPVT) solar collector systems: Part II - Implemented systems, performance assessment, and future directions, Renew. Sustain. Energy Rev., vol. 50, pp. 1566-1633, (2015).

4. O. Z. Sharaf and M. F. Orhan, Concentrated photovoltaic thermal (CPVT) solar collector systems: Part I - Fundamentals, design considerations and current technologies, Renew. Sustain. Energy Rev., vol. 50, pp. 1500-1565, (2015).

5. A. Zahedi, Review of modelling details in relation to low-concentration solar concentrating photovoltaic, Renew. Sustain. Energy Rev., vol. 15, pp. 1609-1614, (2011).

6. G. Bonsignore, A. A. Gallitto, S. Agnello, M. Barbera, R. Candia, M. Cannas, A. Collura, I. Dentici, F. M. Gelardi, U. L. Cicero, F. M. Montagnino, F. Paredes, and L. Sciortino. Electrical-optical characterization of multijunction solar cells under 2000X concentration, AIP Conf. Proc., vol. 1616, pp. 102-105, (2014).

7. G. Bonsignore, A. A. Gallitto, S. Agnello, F. M. Gelardi, L. Sciortino, A. Collura, U. L. Cicero, S. Milone, F. M. Montagnino, F. Paredes and M. Cannas. CHP Efficiency of a $2000 \times C P V$ System with Reflective Optics, pp. 1-5, (2015).

8. F. Paredes, F. M. Montagnino, P. Salinari, G. Bonsinore, S. Milone, S. Agnello, M. Barbera, F. M. Gelardi, L. Sciortino, A. Collura, U. L. Cicero and M. Cannas. Combined Heat and Power Generation with a HCPV System at 2000 Suns, pp. 2-7, (2015).

9. L. Sciortino, S. Agnello, M. Barbera, G.
Bonsignore, A. Buscemi, R. Candia, M. Cannas, A. Collura, G. D. Cicca, F. M. Gelardi, U. L. Cicero, F. M. Montagnino, G. Napoli, F. Paredes, L. Spallino and V. Salvo Direct sunlight facility for testing and research in HCPV, AIP Conf. Proc., vol. 1616, pp. 158161, (2014).

10. EMCORE, Triple-junction solar cell for terrestrial applications. CTJ photovoltaic cell$10 \mathrm{~mm} \times 10 \mathrm{~mm}$. Datasheets Emcore, (2012).

11. A. Kribus, D. Kaftori, G. Mittelman, A. Hirshfeld, Y. Flitsanov, and A. Dayan, A miniature concentrating photovoltaic and thermal system, vol. 47, pp. 3582-3590, (2006).

12. G. Mittelman, A. Kribus, and A. Dayan, Solar cooling with concentrating photovoltaic/thermal (CPVT) systems, vol. 48, pp. 2481-2490, (2007).

13. C. Renno, Optimization of a concentrating photovoltaic thermal $(C P V / T)$ system used for a domestic application, Appl. Therm. Eng., vol. 67, pp. 396-408, (2014).

14. C. Renno and F. Petito, Experimental and theoretical model of a concentrating photovoltaic and thermal system, Energy Convers. Manag., vol. 126, pp. 516-525, (2016).

15. Meteonorm v. 7.1, Global meteorological database for Engineers, Planners and 403 Education, Meteotest, Bern, Switzerland, (2017).

16. Y. A. Çengel and M. A. Boles, Thermodynamics: An Engineering Approach, 8th edition. McGraw-Hill, (2015).

17. Mitsubishi Electric, (Online). Available: https://www.mitsubishielectricsolar.com/produc ts/residential/solar modules. (Accessed: 07Aug-2018).

18. F. Famoso, R. Lanzafame, S. Maenza, and P. F. Scandura, Performance comparison between low concentration photovoltaic and fixed angle PV systems, Energy Procedia, vol. 81, pp. 516525, (2015).

19. U.S. Department of Energy, Engineering Reference, no. EnergyPlus ${ }^{T M}$ Version 8.7 Documentation. (2016).

20. D. L. Evans, Simplified method for predicting photovoltaic array output, Sol. Energy, vol. 27, pp. 555-560, (1981)

21. J. Settino, T. Sant, C. Micallef, M. Farrugia, C. S. Staines, J. Licari and A. Micallef. Overview of solar technologies for electricity, heating and cooling production, Renew. Sustain. Energy Rev., vol. 90, pp. 892-909, (2018). 